\title{
気管食道㾞に対する縦隔気管再建
}

\author{
青地 克也・西岡 信二・西川 邦男・小池 聰之

\section{Reconstruction of the Mediastinal Trachea for the Tracheoesophageal Fistula}

\author{
Katsuya Aoji, Shinji Nishioka, Kunio Nishikawa and Satoshi Koike \\ (Shikoku Cancer Center Hospital)
}

\begin{abstract}
A case of tracheoesophageal fistula in a 59-year-old man who had previously been treated for esophageal carcinoma and mesopharyngeal carcinoma was reported. Tracheoesophageal fistula was caused by poor blood circulation in the trachea after surgery and radiotherapy. Reconstruction of the mediastinal trachea for the tracheoesophageal fistula via partial sternectomy was carried out and a mediastinal tracheostoma was created using a musculocutaneous flap. The use of a musculocutaneous flap allows reliable closure of the resulting mediastinal and sternal defect.
\end{abstract}

Key words: tracheoesophageal fisutula, tracheal reconstruction, mediastinal tracheostomy, musculocutaneous flap

はじめに

後天性気管食道瘦は, 悪性腫瘍によるものが 大半を占め，それ以外には異物や化学薬品の誤 與，長期気管内挿管や気管カニューレによる圧 迫壊死, 感染症, 外傷性によるものがある112). 今回我々は, 胸部食道癌治療 6 年, 中咽頭癌治 療 4 年を経過して, 手術操作, 放射線療法など による血行不全が原因と考えられた気管食道瘦 形成の稀な症例を経験したので，これを報告す るとともに本症例に施行した縦隔気管再建, 縦 隔気管孔作成の問題点について若干の文献的考 察を加えて報告する.

\section{症例}

患者：59歳, 男性, 異時性重複癌.

主訴：気管食道瘦による誤與.
既往歴 :

第 1 癌; 1985年 8 月, 近医より食道癌疑いで 当院放射線科紹介となった．上部消化管内視鏡 では上門歯列より $35 \mathrm{~cm}$ の胸部中部食道右後壁 に $1 / 3$ 周, $3 \mathrm{~cm}$ 幅の表在性の早期食道扁平上 皮癌を認めた。放射線療法として外照射 $40 \mathrm{~Gy}$, 腔内照射 (RALS) 15 Gy にて腫瘍は一時消失し た. しかし，8 カ月後, 局所再発し右開胸食道 亜全摘, 後縱隔経路頸部食道全胃吻合術を施行 した.手術所見は食道癌取扱い規約 $\mathrm{A}_{0} \mathrm{~N}_{0} \mathrm{Pl}_{0} \mathrm{M}_{0}$, Stage $I$, リンパ節郭清 $R_{2}$, 根治度 $C_{3}$, 絶対的 治瘉切除であったが, 病理組織学的検索で, 胸 部上部から腹部食道にかけて深達度 ep, $\mathrm{mm} の$ 表在性多発病巣が認められた（図 1)。このた め頸部食道に術後照射 $60 \mathrm{~Gy}$ を追加した. 以後 経過は良好であったが，1988年 7 月に右中内深 
頸領域にリソパ節転移が出現，右根治的頸部郭 清術を施行. その後, 再発を認めなかった.

第 2 癌；1990年12月, 第 1 癌治療 4 年後, 両 側舌根部から喉頭蓋谷，喉頭蓋舌面に及ぶ潰痬 形成性の腫瘍が出現した。組織検査では，中分 化型扁平上皮癌であった．頸部リンパ節転移， 遠隔転移, 食道癌の再発は認められなかった。 異時性に出現した重複癌として, 術前化学療法 $(\mathrm{CDDP}+5-\mathrm{FU}, 1$ クール) 後, 喉頭・中咽頭前 壁摘出術, 左機能的頸部郭清術, 左大胸筋皮弁 による舌根部再建術を施行した（図 2 ）. 以後, 第 1 癌, 第 2 癌ともに再発, 転移なく経過良好 であった。

現病歴: 第 2 癌根治術後 2 年の1992年 4 月, 気管膜様部々再建胃管前壁の間に瘦孔が出現し

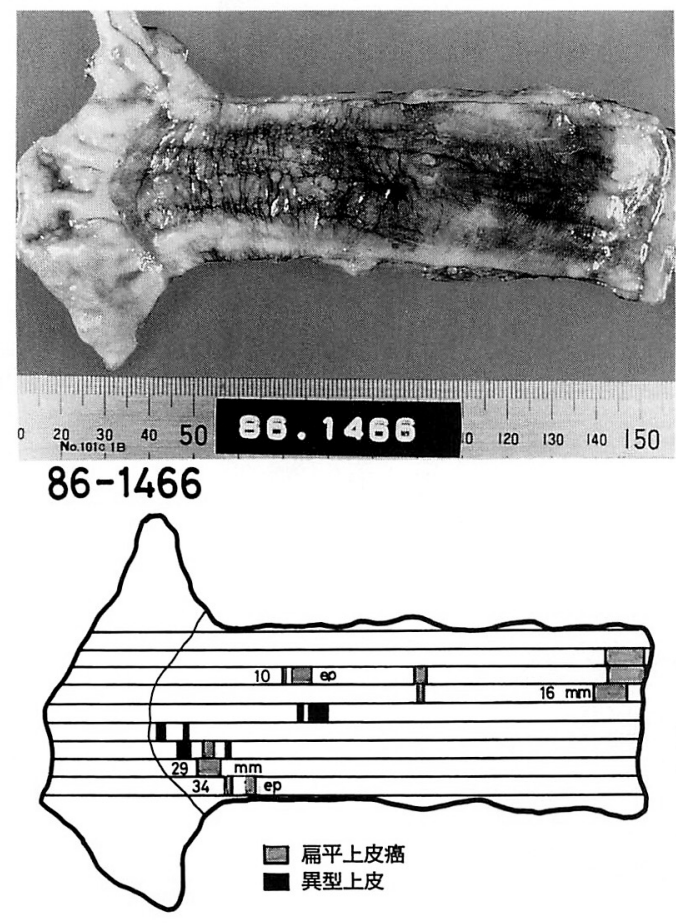

図 1 食道摘出標本

\section{上：新鮮標本ルゴール染色像} 下: 再構築像

胸部から腹部食道にルゴール不染域が散在 し, 深達度 ep, $\mathrm{mm}$ の扁平上皮癌, 異型上 皮の多発を認める。
入院となった．入院時には $5 \times 3 \mathrm{~mm}$ 大の小さ な瘦孔（図 3 ）であったが，唾液が気管に流入 し軽度の誤曣性肺炎を併発していた，頸部リン パ節は触知せず，気管膜様部瘦孔周囲にも腫瘍 は認められなかった。また食道硬性鏡検査でも 食道癌の再発は認められず, 頻回の手術操作, 放射線照射などによる血行不全が瘦孔の原因で あると考兄られた。絶领絶食, 中心静脈栄養に 上る保存的治療を施行するも奏功せず次第に瘦 孔拡大， 3 週間で約 $15 \times 10 \mathrm{~mm}$ の大きさとな ったため，瘦孔閉鎖術を施行した。

手術所見：胸鎖関節を含む胸骨柄切除にて上 縦隔に到達, 気管膜様部と胃管の㾇孔部位を剥 離，胃管穿孔部は縫縮した，瘦孔部を含む気管 後壁打上び気管孔周囲の皮膚を切除し，右大胸 筋皮弁にて気管後壁を再建，気管を腕頭動脈の 右方に通し，縦隔気管孔を作成した（図 4). また，大胸筋の筋体を上縦隔に移植，死腔の充 填，気管孔と血管系の分離を行った。しかし， 気管の血流不全のためと思われる気管壁の壊死， 気管と大胸筋皮弁との縫合不全, 上縱隔の感染 をきたし，術後 9 日目に腕頭動脈が破裂，緊急 手術となった. 腕頭動脈は感染のため, 長さ 2 $\mathrm{cm}$ ，全周の約 $1 / 3$ が壊死となっていた，壊死 部を除去，ナイロン系で縫合，止血した，気管 は注ぼ全周性に壊死となって括り，気管分岐部 上 $3 \mathrm{~cm}$ まで切除を行った. 気管再建, 腕頭動 脈縫縮部の補強のため $10 \times 9 \mathrm{~cm}$ の左広背筋皮 弁を挙上したが, 挙上途中に再び腕頭動脈縫合 部からの大出血を認めたため, やむを得ず腕頭 動脈を結禁切断し止血を得た。さらに広背筋皮 弁をロール状にして気管形成を行い，その筋体 を上縦隔に充填し手術を終了した（図 5 ).

術後経過：気管の壊死，広背筋皮弁々気管の 縫合不全もなく経過良好と思われた。しかし， 術後 7 日目に上縦隔ドレナージ，胸壁皮膚欠損 部位に胆汁の流出を認め, 胃管㾇孔部位の縫合 不全と考兄られた．保存的な処置による瘦孔の 自然閉鎖を期待したが，胆汁による污染から再 度縦隔感染を生じ，30日後に気管と広背筋皮弁 
の縫合不全, 気管断端の壊死が認められ, 約50 日後, 腕頭動脈からの再出血と思われる大出血 のため失血死した。

\section{考察}

後天性気管食道瘦孔は，悪性腫瘍によるもの が大半を占め, それ以外には異物や化学薬品の 誤與, 長期気管内挿管や気管カニューレによる 圧迫壊死，感染症，外傷性によるものが報告さ れている(1)2)。本例は, 胸部食道癌, 中咽頭癌 の異時性重複癌で, 各々根治後, 6 年, 4 年を 経過し，腫瘍が制御されているにもかかわらず， 気管膜様部之食道（実際には挙上胃管）に瘦孔

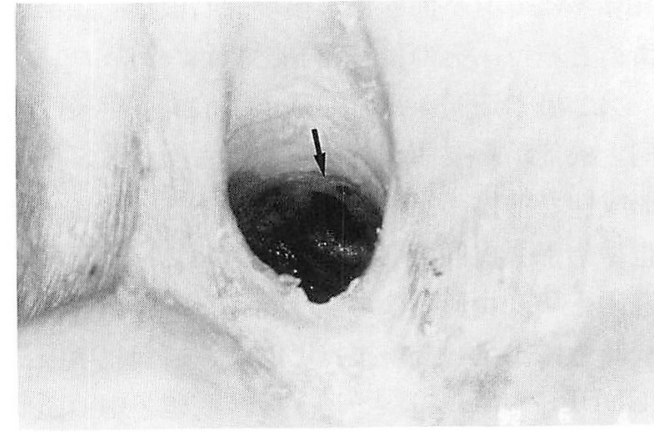

図 3 気管食道瘻

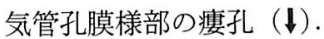

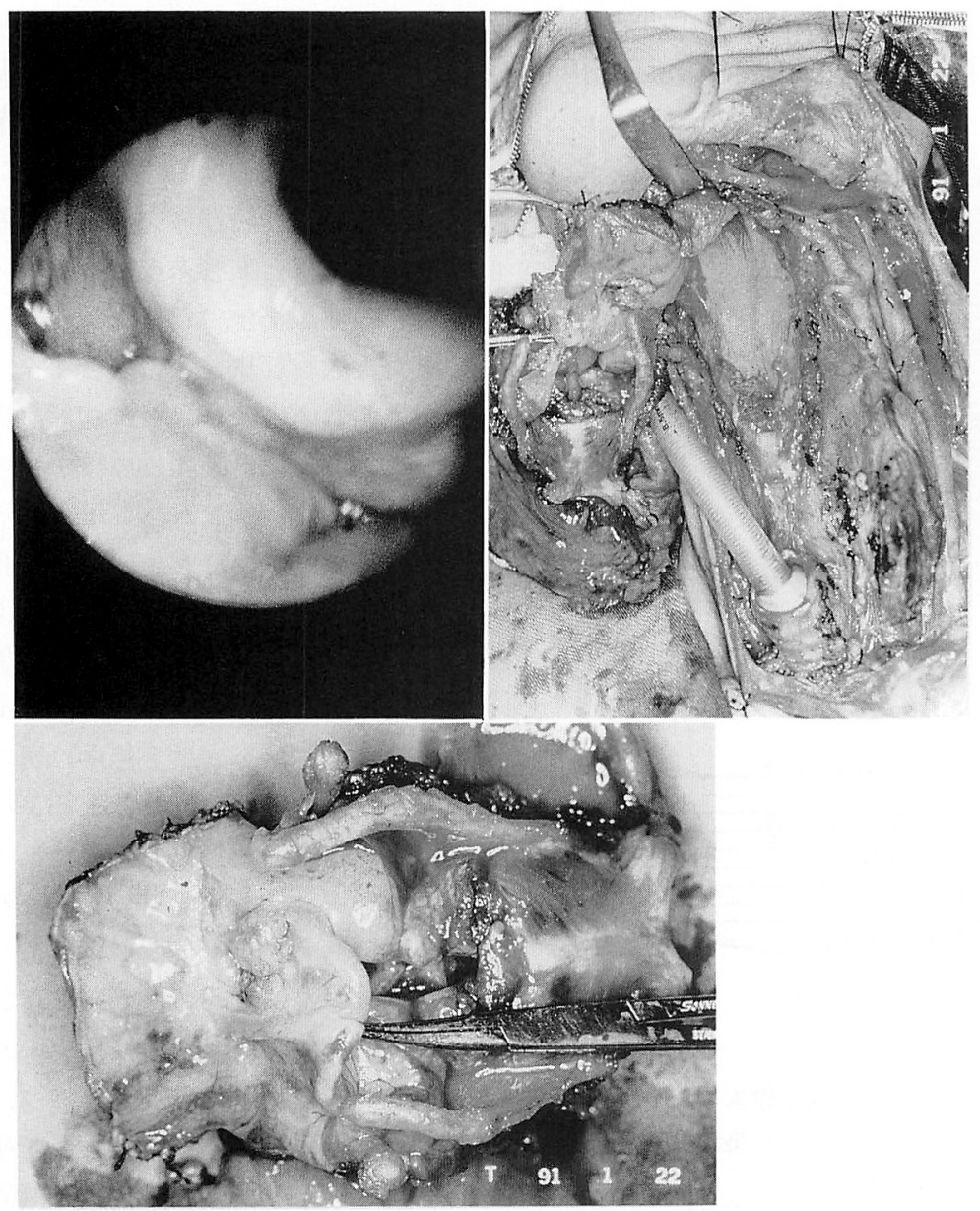

図 2 中咽頭癌

左上 : 内視鏡所見 右上 : 術中所見 下: 摘出標本 
が形成されるという稀な症例であった．本症例 そおける瘦孔形成の成因として, 頻回の手術操 作拉よび放射線照射による気管周囲の血流不全 が考兄られた. 手術操作に関しては, 縦隔郭清 を伴ら食道癌根治術, 中咽頭癌根治術, 両側頸 部郭清術が施行されて扣り, 気管周囲に対する
剥離操作，気管支動脈結禁などによる血流低下 が存在していたと思われた。また放射線照射に 関しても，食道癌初回治療時に胸部食道に，根 治術後に頸部食道に，ともに根治照射が行われ 気管周囲にもかなりの線量が照射されていたと 推測された．気管食道瘦形成の原因として挙上

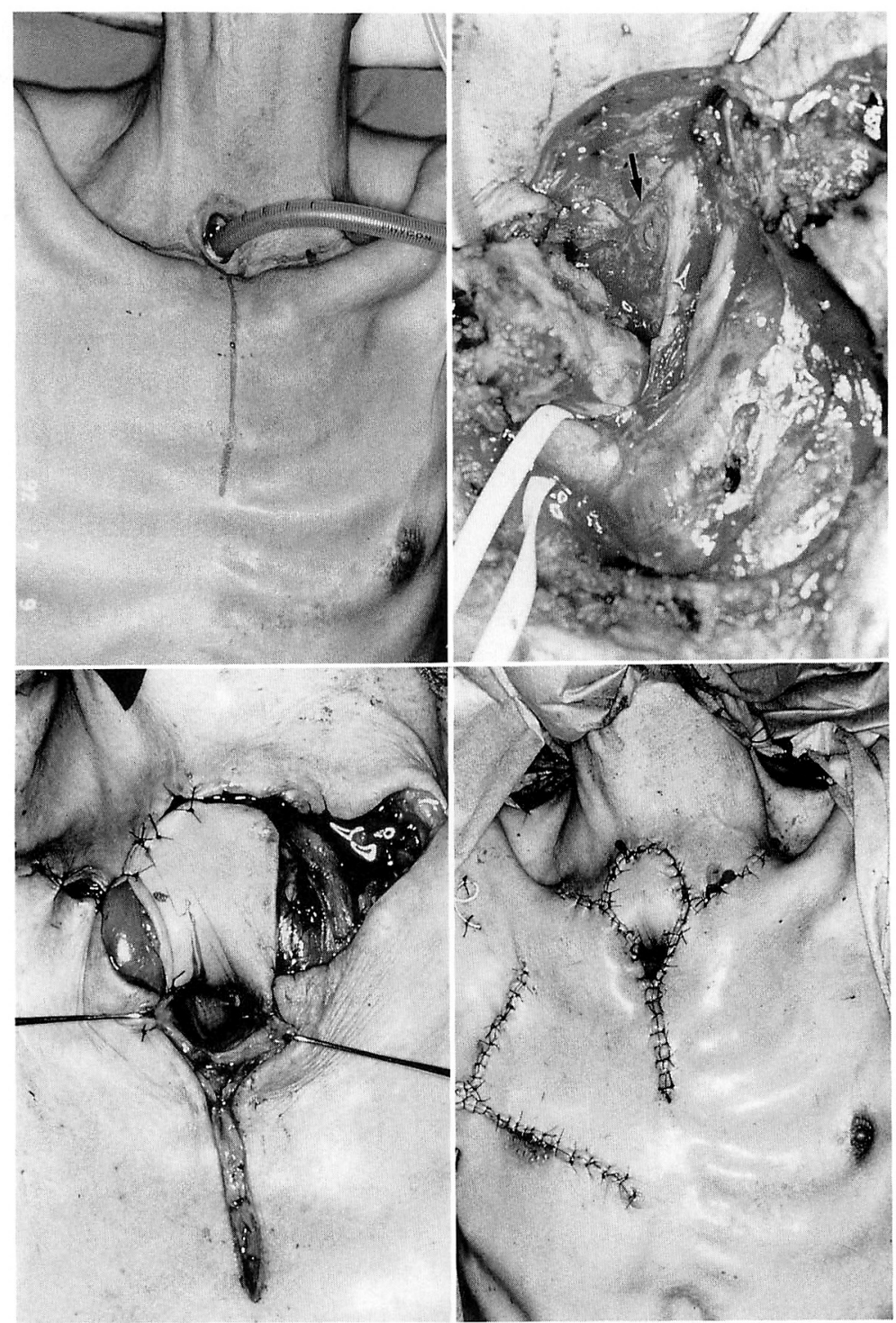

図 4 瘻孔閉鎖術

左上：皮切

右上：気管食道癗を切離，矢印は食道瘦孔，テーピングは腕頭動脈 下：気管後壁を右大胸筋皮弁で再建 
胃管に生じた胃潰瘍も考慮されたが，全胃管作 成時に迷走神経幹は切断されているためこの可 能性は低いと考えられた。

本例の気管食道瘻に対する瘦孔閉鎖術では, 㾇孔部の切離と縦隔気管の再建, 縦隔気管孔作 成が必要となった，縦隔への到達法として，胸 骨縦切開 3 ）むしくは胸骨上部と胸鎖関節の切 除，あるいは胸骨上部，胸鎖関節，第 1 第 2 胁骨の切除などの方法4)5) があるが，今回は， 胸鎖関節を含さ胸骨柄切除を施行した．このア プローチでも気管分岐部上 $3 \sim 4 \mathrm{~cm}$ までの気管 の切除は十分可能であった.

縱隔気管再建, 縦隔気管孔作成には, (1)胸骨 柄を切除し，気管断端と前胸部皮膚を直接縫合 する方法 ${ }^{4)}$, (2)前胸部に 2 本の平行な横切開を 置き双茎皮弁を作成し，その中央に穴をあけて 気管断端と縫合する方法6), (3)筋皮弁を用いて 気管孔を形成する方法233などがあり，さらに これらに加えて様々な手術法7)が工夫されてい る. 最も重要なことは, 縦隔の死腔形成, 感染, 気管壞死, 大血管の露出, 破裂といった術後合
併症をいかに予防するかという点である。その 他, 肺へル =ア, 縦隔腫瘍, short trachea 起因する気管支炎の反復なども報告されてい る8).

本症例では, 瘦孔が気管膜様部に存在してい たため, 膜様部のみ切除し, 気管後壁の再建に 大胸筋皮弁を用い，その筋体で縱隔の死腔を充 填した.しかし，剥離した気管壁の血行が之し く気管壊死となり腕頭動脈の破裂を生じる結果 となった. 術中, 気管の血流が良行でないと判 断し，気管断端から良好な出血が認められるま で気管を切断すべきであったと反省させられた． また術後，気管壊死となった時点で，加藤ら ${ }^{9)}$ の報告にも述べられているように，ためらわず 再手術し, 気管切除, 再建を施行していれば腕 頭動脈の破裂は回避可能であったかもしれない， 一方，止血困難な腕頭動脈破裂に対する処置と して腕頭動脈結紮の可否が問題となるが，我々 の症例では結紮後も右上肢には特別な合併症は 認められなかった。

縦隔気管再建, 縦隔気管孔の作成に筋皮弁を

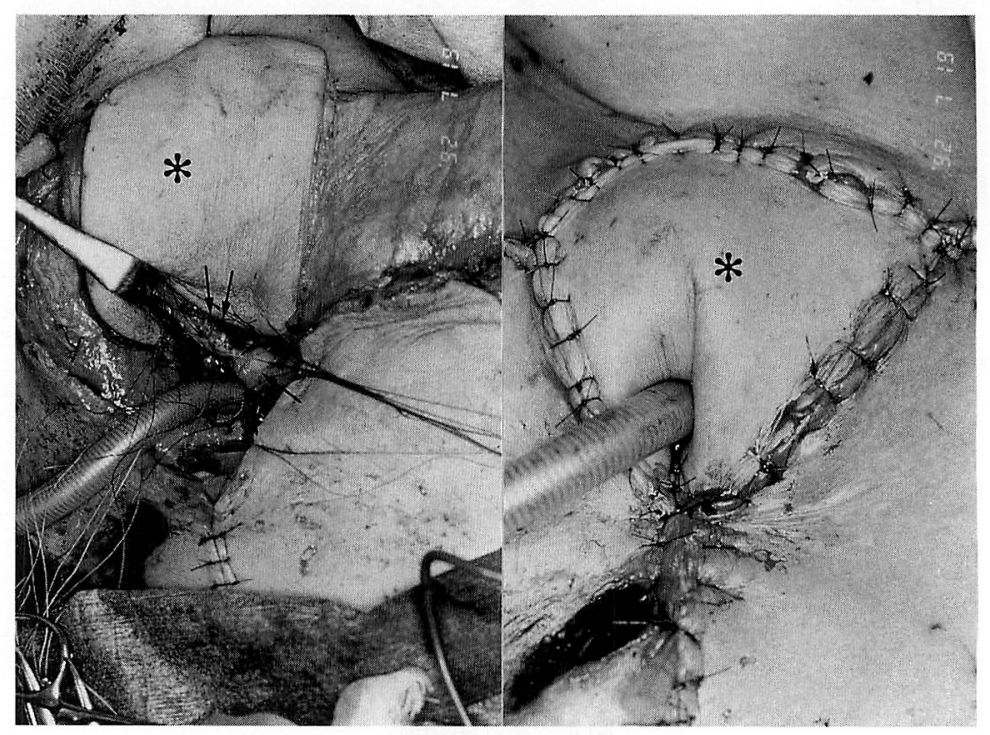

図 5 腕頭動脈破裂による緊急手術

腕頭動脈結紮（〕）と広背筋皮弁による縦隔気管再建, 縦隔気管孔作成. * ; 広背筋皮弁 
用いる場合, その筋体で, 縦隔の死腔を充填し, 大血管と気管との隔離, 気管壁の被覆, 補強を することが可能である．大胸筋を用いた第 1 回 目の縦隔気管再建では, 気管壁の血行不全が著 しく，気管壊死となり大血管破裂となったが， 第 2 回目の広背筋での再建では, 気管再建に問 題なかった. 腕頭動脈破裂より約 2 力月延命で きたが，胃管の瘦孔の縫合不全が縦隔の再感染 の引金となり，非常に残念な結果となった。胃 管の瘦孔に対しても縫縮するだけでなく，血行 の豊富な筋皮弁などで再建すべきであったと考 えられた。

$$
\text { まとめ }
$$

1 ）食道癌, 中咽頭癌根治後に生じた, 気管 の血行不全が原因と考えられた気管食道瘦を経 験した。

2 ) 気管の血行不全は, 頻回の手術操作, 放 射線照射によるものと思われた。

3 ）筋皮弁を用いた縦隔気管再建, 縦隔気管 孔の作成を施行した.

稿を終えるにあたり，御指導と御校閲を賜りまし た恩師増田 游教授に深甚なる感謝の意を表します。

\section{文 献}

1）石井 昇, 松田 均, 畠山 理, 他: 長期気管 内挿管による気管食道瘦に対する手術. 日胸外
会誌 $40: 775 \sim 776,1992$.

2）小池聰之, 小川晃弘, 宇野欽哉, 他 : 気管孔再 発癌に対する外科的治療. 日気食会報 $38: 323$ $\sim 328,1987$.

3) Gomes MN, Kroll S and Spear SL : Mediastinal tracheostomy. Ann Thorac Surg $43:$ 539 543, 1987.

4）村上 泰, 向井 將, 浅岡一之, 他: 前絽隔を 経由する永久気管瘦造設手術. 日気食会報 28 : 300 305, 1977.

5) Grillo HC and Mathisen DJ : Cervical exenteration. Ann Thorac Surg 49 : 401 409, 1990.

6) Grillo HC : Terminal or mural tracheostomy in the anterior mediastinum. J Thorac Cardiovasc Surg $51:$ 422 427, 1966.

7）坂口正範, 松尾 清, 飯田 太, 他: 広頸筇皮 弁を用いて気管後壁の再建を行った頸部食道癌 の 1 例. 耳喉頭頸 $62: 63 \sim 67,1990$.

8）藤田博正, 川原英之, 日高正晴, 他: 頸胸境界 部食道癌の治療上の問題点とその対策. 日気食 会報 $36: 500 \sim 510,1985$.

9）加藤抱一, 飯塚紀文, 渡辺 寛, 他: 頸部境界 部食道がんに対する，食道拔去術及び Grilloの 手術の応用. 日胸外会誌 $31: 706 \sim 707,1983$.

$$
\left(\begin{array}{l}
\text { 別刷請求先: 青地克也 } \\
\text { †7 } 790 \text { 松山市堀之内 } 13 \\
\text { 国立病院四国がんセンター耳鼻咽喉科 }
\end{array}\right)
$$

